\title{
An artistic research proposal from an A/R/TOGRAPHY perspective: a study of the first movement of Strauss's Oboe Concerto
}

\author{
Maria Paz López-Peláez-Casellas (Universidad de Jaén, Jaén, Espanha) \\ mlpelaez@ujaen.es \\ Cecilio García-Herrera (Conservatorio Superor de Música de Jaén, Jaén, Espanha) \\ ceciliogarciaherrera@gmail.com
}

\begin{abstract}
This article is a contribution to the debate which has been taking place for some years now around the use of artistic research methodologies in conservatories in Spain. To be precise, it supports a methodology centered on artistic activity, which is not conditioned by the dictates of science and the need to obtain results. Within this current of thought, we have developed a new methodology of artistic research, a/r/tography, which is adapted from Fine Arts, and is aimed at teachers in music conservatories and makes it possible to simultaneously research, perform and teach a piece of music. This methodology is applied to the first movement of Strauss's oboe concerto, an especially complex work from a breathing perspective.
\end{abstract}

Keywords: Artistic research; Methodology; A/r/tography; Conservatories.

Uma proposta de pesquisa artística de uma perspectiva A / R / TOGRAPHY: um estudo do primeiro movimento do Concerto para Oboé de Strauss

\begin{abstract}
Resumo
Este artigo é uma contribuição para o debate sobre a utilização das metodologias de pesquisa em arte nos conservatórios de música. Defendemos uma metodologia centrada na atividade artística, não condicionada pelas regras da ciência e pela obtenção de resultados. Por isso, seguindo essa linha de pensamento, desenvolvemos uma nova metodologia de pesquisa em arte, adaptada às Belas Artes, à a/r/tografia, dirigida a professores de conservatórios de música, possibilitando a realização conjunta da pesquisa, interpretação e educação de uma obra musical.
\end{abstract}

Palavras-chave: Pesquisa em arte; Metodologia; A/r/tografia; Conservatórios.

In recent years, there has been a gradual reform taking place of the paradigms for research carried out by professional musicians in Spain. It was, to be precise, the Bologna Process and the creation of the European Higher Education Area which precipitated a degree of concern about new forms of research among music professionals in Conservatories (LÓPEZCANO; SAN CRISTÓBAL, 2014). Even though these Artistic Research methodologies seem to be the best-suited to the needs of musicians (giving value to the creative process), these methods have certainly not yet found their way into Spanish conservatories.

In practice, these centers continue to favor, for the most part, musicological research based on analysis of the life and work of a composer, and work involving the harmonic analysis of a piece, which may (or may not) then be played in the final assessment. The acceptance of Artistic Research methodologies is entirely different among Spanish visual artists, even if in this sphere they bring a different kind of problem (MOLTÓ, 2016; BORGDORFF, 2010; LÓPEZ-CANO, 2013). It is a problem whereby the action of creating simultaneously employs reflection, critical analysis, the acquisition of conclusions and the action itself, all of which together provide a path to understanding how knowledge is constructed (MORENO; VALLADARES; MARTÍNEZ, 2017). Although at the outset we could argue that this is all equally applicable to the process of creating carried out by musical instrumentalists, concerns with solving technical problems and improving the performance of a work mean that, as Pace has observed (2015), there is frequently no conscious reflection on the artistic practice that is taking place. 
TheDublinDescriptors(2004), whodeterminethecomponentsofofficialstudieswithin the European Higher Education Area framework, established that artistic practice, in order to be considered research, must involve a contribution that is not only original but also deliberate. The idiosyncrasy of conservatory music studies and the level of resistance towards adopting new research methodologies (LÓPEZ-CANO, 2013) are the main reasons why we have been moved to develop an Artistic Research proposal for musical instrumentalists. The methodology we propose is based on three main facets which are found in any musician who teaches in specialized centers, that is: educational, investigative and artistic. To be precise, it involves the adaptation from musical research of a methodology which comes from Fine Art, a/r/tography, which we will elaborate on through research connected to a doctoral thesis undertaken by an oboe teacher in a Higher Conservatory of Music. This work - innovative as far as we can see - will help us in our defense of the suitability of this method of artistic research in Music Conservatories, since it enables the combined research, performance and teaching of a piece of music. In this specific case, the a/r/tographic method used in a research work on the first movement of the concerto Richard Strauss's Concerto for oboe and orchestra and the breathing problems caused by the excessively long phrases in the first movement. Before explaining the characteristics of this methodology and its application and adaptation to the sphere of music, we will provide a brief overview of Artistic Research and its presence in Music Conservatories, since, as Luca Chiantore notes, this is a subject that dwells within an Intellectual, institutional and artistic debate (LÓPEZCANO; SAN CRISTÓBAL, 2014).

\section{The debate around artistic research in music}

As Borgdorff (2010) has stated, the debate that has been under way for some years around Artistic Research methodologies has barely reached the field of music. Only in the last few years have we witnessed a measure of interest in 'the right of existence' of new forms of research using art rather than talking about art (ZALDÍVAR, 2008) in the sphere of music; that is to say, in the possibility of using methodologies which are centered on the process of the creation itself of a piece of music. The main obstacle for those applying these methodologies (as their detractors highlight) concerns when artistic practice can be considered research. To follow a narrow thread, the question could also be expanded to ask what we can consider as research.

In general terms, those who defend the use of Artistic Research in music point out that in this kind of research both the questions and problems that need solving, as well as the knowledge generated, come directly from artistic experience; these are the very elements that artistic practice converts into research and which can only be resolved by professionals working within these fields (PACE, 2015). This is the view of Zaldívar (2010), López-Cano (2013) and Brown and Sorensen, who in broader terms affirm that "research refers to the act of finding out about something and is involved in learning about a topic, extending a skill, solving a problem and so on. [...] almost all creative practice involves this general type of research, and often lots of it” (BROWN; SORENSEN, 2008, p. 153).

Yet while there is a narrow connection between research and artistic practice, for Borgdorff one should not be identified with the other since, as he strongly argues (2010, p. 8): "if everything is research, then nothing is research any more". These are the reasons which lead us to position ourselves beside a long list of theorists including Borgdorff (2010; 2015), Pace (2015), López-Cano (2013) or Sligter (2007), who argue that in order for artistic practice to be considered Artistic Research, the researcher-artist must produce a report 
which shows an awareness of the artistic process and brings together the reasons why they take some decisions instead of others. In the words of Sligter (2007, p. 44), "we may speak of research if the performer explicitates or shares his practical knowledge and is prepared to systematically ask himself which prior concepts have guided his actions.” To think that we can forego such a report is "too utopian" (PACE, 2015, p. 67).

However, as we noted at the start, this question, of the viability of Artistic Research in music, and even whether it can be considered as research, is far from being answered. Of the negative arguments surrounding Artistic Research, one of the most striking comes from John Croft (2015). Referring to the field in which he is an expert, musical composition, he argues that "There are, by and large, two kinds of composers in academia today: those who labor under the delusion that they are doing a kind of 'research', and those who recognize the absurdity of this idea" (CROFT, 2015, p. 6). In his opinion, the work carried out in the creation of a piece of music offers no response to traditional research questions, and in the event that it did, the answer would already be known in advance, which renders it invalid. For Croft (2015), a piece of musical research - to be considered as such - is obliged to follow the lines marked out by the scientific disciplines and there must be limits placed on the value of the process since the only truly important thing is the result, in this case, the composition of the piece of music.

Croft's thinking is not unusual among Spanish academics; indeed, it is present in many Higher Conservatories in Spain. Although, as has been shown, there exists more interest in differentforms ofresearch-owingtotheseconservatoriesenteringtheEHEA(ZALDÍVAR, 2005) - the final projects which students must complete to achieve their degrees continue to follow thesewell-recognizedand oft-repeatedformatsconsistingofharmonicand/ormusicalanalysis. And even when the possibility of carrying out Artistic Research in music is recognized, we find the view that, for it to be done properly, it must follow - in its methodological development - the empirical sciences, since these can give "algunos significados a este terreno necesitado de claridad” (PÉREZ-LÓPEZ, 2010). This link with experimental sciences would suppose a framework for the Artistic Research elements along the following lines: 1) an experiment, equipped with a good dose of transparency and rigor; 2) a hypothesis, expressed in the clearest terms possible and 3) results, formulated in a way that arrive in a way that achieve the greatest possible precision (PÉREZ-LÓPEZ, 2010). Summing up, Artistic Research in music "debe ser llevad(a) a cabo con el criterio y el rigor propio de la investigación científica” ${ }^{2}$ (2010).

We agree with Pérez-López that in order to build a research culture in musical and artistic spheres and reinforce the role of musicians in cultural life, it can be interesting to know different methodological tools, though we disagree openly with the view that thanks to these, one can produce research into artistic and musical territory with greater coherence (2010). The knowledge of different methodologies and research structures does not ensure their unquestioning acceptance, as we cannot follow a process of investigation "como quien sigue unas instrucciones de montaje”3 (MORENO; VALLADARES; MARTÍNEZ, 2017, p. 32). The problem, in our opinion, arises the moment that one considers that the only form of research belongs to the sciences as this would then mean, as Habermas (1986) and Lyotard (1987) both point out, that the only way of understanding reality comes from the sciences too. In this sense, Hernández (2008) pointed out how, after the crisis in the assumptions of positivism and scientism, the concept of research and the way in which it is carried out have advanced, breaking the stereotypes of dualist thinking which have defined us for three hundred years in the West and which regarded as inevitable the separation between the subject who observes and the subject who researches. 
In addition, we cannot forget that this positioning in favor of science leads us towards a dangerous "methodological essentialism" (REEVES, 2015). To defend the scientific paradigm is not only reductionist but can prove extremely damaging since it does not only place a question mark beside artistic or performative research but does the same of all research into the Humanities with its different branches of knowledge. There are many forms of research and their borders do not have to be defined by the dictates of science (SLIGTER, 2007). Nor does the objective have to be purely results-based. The method adopted for research should be determined by reflection (although this in itself can also condition it) but it should never become such a central element that it reaches the point of misshaping projects by trying to incorporate them into structures taken from other spheres, for which they are not a natural fit (MORENO; VALLADARES; MARTÍNEZ, 2017, p. 29$)^{4}$.

These debates over what is and what isn't research and the great variety of forms of Artistic Research undertaken in the area of music (LÓPEZ-CANO, 2013) have produced many doubts which arise among those who opt for this methodological approach. Also, in our opinion, it means that this approach is not developing as smoothly as it has done, for example, in the visual arts. These are the reasons that led us to make an Artistic Research music proposal which, though coming from a Fine Arts methodology, is not constrained by it. It is not presented as a watertight compartment but as something we offer as one possibility among many. The main thing, in our opinion, is that this proposed methodology does not distance music specialists from their own creative and interpretative practice something which, as we concur with Zaldívar (2008), must be a priority for Conservatory teachers.

\section{A/r/tography as an Artistic Research proposal}

This methodology is innovative for its use of musical practice. It was applied to a research project undertaken on the Concerto for oboe and small orchestra in D major, Op.144 (trV 292) by Richard Strauss $(1947,1948)$. When he wrote the Concerto for Oboe, Strauss was 81 years old and it was the first time he had sought to give this instrument prominence with a soloist and orchestra. This Concerto is one of the last four works he composed, representing the final output of his career as a composer. The idea for this choice of work came from the problems with breathing caused by the first movement - problems faced by four final-year students from the undergraduate program. The enormous challenges which, because of its difficulty, this work presented when used in a teaching context, led us to employ this artistic and investigative experience in the process of teaching-learning; that is to say, to count on the close collaboration of the roles which converge and interact in conservatory music: investigative-artistic-educational. As Marín Viadel notes, in this sense, "en lugar de dislocar cada una de estas tres perspectivas en sus respectivas actividades profesionales ipor qué no reunirlas bajo un misma unidad conceptual y vital?” (2011, p. $226)^{5}$. It is precisely from this that a/r/tography takes its name, and it explains its first three letters: Artist, Researcher and Teacher, which together also form the word 'art'.

This research method, developed at the University of British Columbia (Canada) and conceived for Fine Arts, originated with Rita L. Irwin. For this researcher (IRWIN et al, 2006), a/r/tography is intrinsic to oneself - as is the role of artist/researcher/teacher - and it involves self-inquiry. Within the research group that Irwin leads, Peter Gouzouasis (2006) represents the current music-centered methodology; in particular, his work establishes the relationship - on a theoretical level - between methodological concepts of a/r/tography 
(contiguity, living inquiry, metaphor and metonomy, opening reverberations and excess) and different aspects and functions of music.

It proved complex for us to adopt this method for a music research project, especially given our chosen requirements that each of the different roles feed off each other and that the students participate in the process from the very start. Yet what, at the outset, appeared as potentially an added difficulty - given we could find no references to the use of these methods among conservatory teachers - became a positive for us in the end as it obliged us to reflect on the process and to take nothing for granted.

\section{On the process}

In general terms, the $\mathrm{a} / \mathrm{r} /$ tographic research undertaken led us to a deep understanding of the breathing process in Strauss's Concerto for oboe (1947). The information, in general, came from different sources; aside from the existing bibliography and discography together with video recordings- the a/r/tographer made use of their own performative experience as an oboist of some prestige and of that of different professional musicians who were interviewed with practical questions about their performances. They even produced different analyses of that piece which focused on the study of different ways of breathing. The objective of all the knowledge acquired was to help students on the Higher Music Studies course to better understand the work. They were not just privy to the knowledge that we gathered throughout the research process, but they also collaborated in acquiring it through their own practicing of the piece, and reflections on it. Keeping in mind all the information obtained, the pupils took their own decisions over the interpretation of fundamental questions like breathing, phrasing or tempo.

The biggest complexity we found in designing and carrying out this work was the task of interweaving the different phases of the process. We did not want the students to simply be given the research results and then have the job of taking them on board and assuming the a/r/tographer's decision as their own; rather, they had a leading role and had to decide on questions of interpretation. To paraphrase Irwin et al (2006), this was about transforming abstract systems of theory and practice into spaces for exchange and reflexivity and relationality within a state of constant movement.

\section{As researcher}

In the role of researcher, the a/r/tographer investigated the features that set apart Richard Strauss - in his style as a composer - as one of the most important figures in music in the 19th and 20th centuries. They studied his instrumental work with the aim of being able to place the composition of the Concerto for oboe within the quite unconventional circumstances which led to its creation. The fact is that he decided to compose this concerto in response to a request he received from a US soldier from the Allied forces (and oboist), John de Lancie, who visited him in May 1945 at the Strauss family residence in Bavaria. To start with - as de Lancie himself related - the composer refused categorically: "I asked him whether he ever thought of writing a concerto for oboe. His answer was a plain 'No!'. That was about the most I could get out of him, so I assumed the whole subject was either of no interest at all, or of no further interest to him." (BROSCHE, 1992, p.180) ${ }^{6}$ However, the composer changed his mind on the matter, as revealed by a letter he wrote to his friend Schuh a short while later, on 6 July 1945: "In the studio of my old age, a concerto for oboe and small orchestra is being 'concocted.' The idea for this [work] was suggested to me by an oboe player from Chicago.” (BROSCHE, 1992, p.180) 
In this research role, it was essential to look into the characteristics and difficulties encountered in performing this piece since its composition. The main problems are found in the first movement of the concerto in which Strauss wrote 55 successive bars wherein the only opportunity to breathe comes from taking advantage from two quaver rests. These extensive phrases cause oboists real problems with their breathing. In the event of failing to devise an adequate strategy for their respiration when performing the work, the oboist can find themselves suffering from a lack of oxygen, which affects their physical state and, in turn, their mental state.

The end product of all this was to understand better the origin of the breathing problems from which oboists suffer and the solutions that have been adopted to counter them, which are: changes to the articulation, and to the tempo in the phrasing, the creation of aerophor ${ }^{7}$, the use of circular breathing, and the elimination and transcription of musical material, among others. With regards to this last-mentioned option, de Lance himself, when performing this work, would transfer parts written for the oboe to other instruments in the orchestra in order to gain some moments where he could rest. (BLOOM, 2005).

In addition, we had to acquire concrete information on the characteristics of composition and of performance in the work. With this goal in mind, we carried out, on the one hand, a formal analysis of the Concerto, and, on the other, a review of the different interpretative decisions taken by important oboists. To this end, we also interviewed musicians who had performed the piece, and watched, with great attention, numerous live recordings of the Concerto which were available on video ${ }^{8}$. Drawing on all of this information and the experiences of oboists, there were spaces created for breathing throughout the whole first movement. We include the following example:
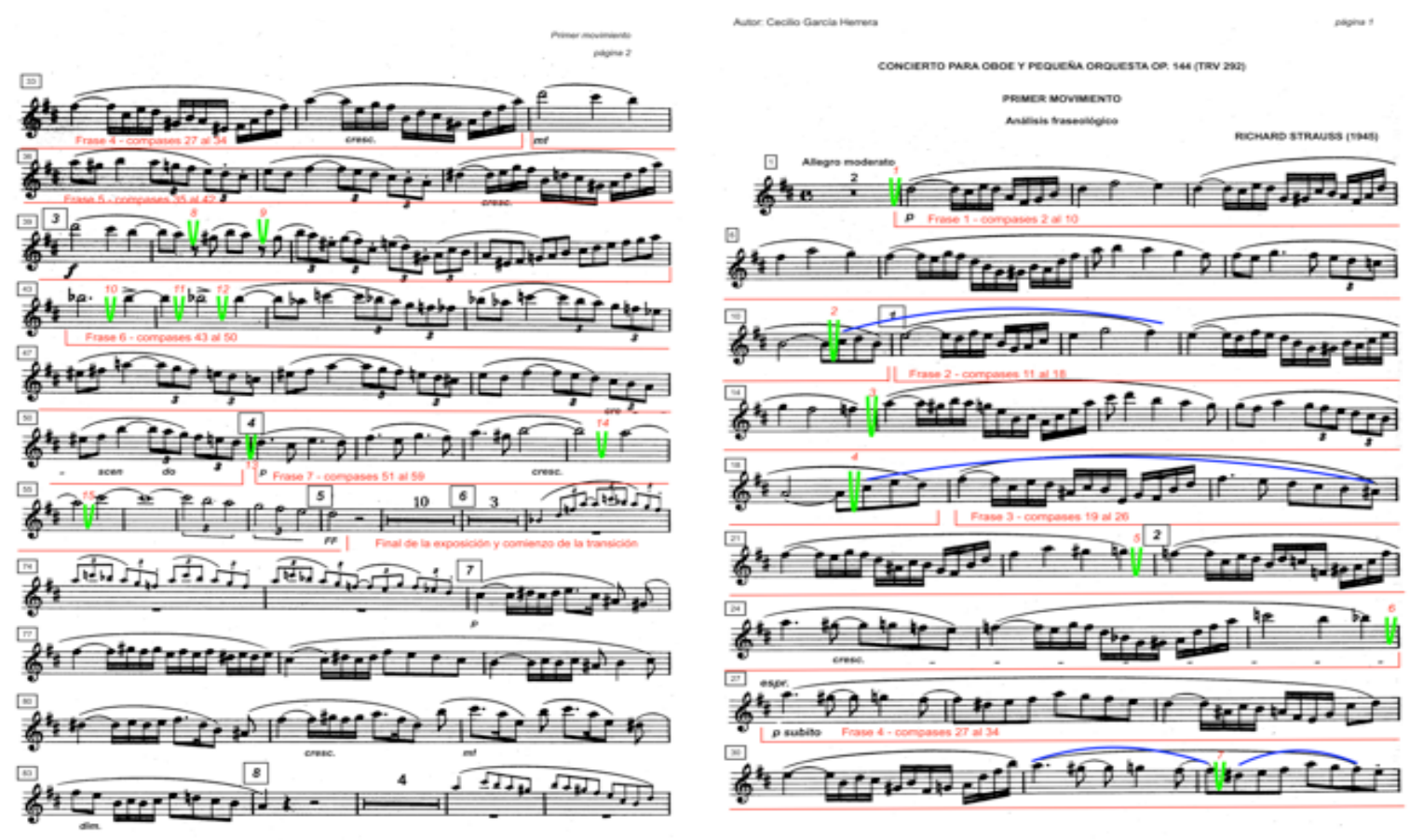

Oboe score for the Concerto for oboe and orchestra in D major Op. 144 (TRV 292) by Richard Strauss. First movement Color green: indicates breath mark Color blue: indicates new ligatures Color red: indicates different phrases 
One of the problems that arose was whether this research phase should precede the performative and educational phases or whether it should coincide with them, taking place at the same time. In the end we agreed that, although all the information we would draw would be needed to take on, with confidence, the performing of the piece - and such a complex piece as this - it would be interesting, especially for the students, to approach it without the knowledge and to be slowly discovering the work and its interpretative possibilities as the research project progressed. In following through this idea, the students were able to face up to the task of performing the Concerto from the first moment and they modified and revised their opinions as their research progressed ${ }^{9}$. We think that this form of action could be especially interesting to instill in the students a passion for research and to make them understand how important it is when taking decisions that they draw on their reflections and do not just seek a technical solution.

\section{As an artist}

From the role of performer, we used the feelings noted by the researcher in the process of building the performance. The interpretation dealt with 1) the interpretative decisions taken by the oboists interviewed, 2) the conclusions drawn after the performance of the Concerto delivered live by different experienced musicians, and 3) the different types of analysis carried out on the work (analytical, formal, phraseological). The objective was to detect the difficulties, which could arise when using different responses to the question of breathing. This information was collected by the $\mathrm{a} / \mathrm{r} /$ tographer in videos in which they explored different possibilities and pointed out what they considered the advantages and inconveniences of each one of them. According to this research method, we tried at every moment to weave together theory and practice so that these become one and the same question.

\section{As a teacher}

As we have shown, the position that we adopted from the start of our work with the Concerto - one taken from a/r/tography in Fine Arts - was the conjunction and superposition of time with the three roles. In accordance with this, and although we are addressing in third place the role of teacher, it must be noted that this phase began together with the previous two. Four oboe students took part, each with different qualities and abilities, both technical and musical. As we have already shown, their participation was recorded in a video diary created specifically for this purpose. In it, the students experimented with different interpretative solutions related to breathing (combination of circular breathing and natural breathing, creating small rallentandi so that the spaces become wider and it is possible to breathe more comfortably, etc.) and to musical expression, which they tried out for themselves while also taking into consideration the teacher's research and artistic work.

This required the artist-researcher-teacher to make their students participants in the process from the start and to encourage them to develop their own interpretation of the work, at the same time as he was doing the same with his own performance. It was a continuous endeavor with these students over a whole semester, one based on observing their maturing process and which comprised debates - in which they revealed their concerns, the solutions found and principal difficulties - various performances and an end-of-course recital, all of which were recorded on video. 


\section{Conclusions}

We believe strongly that it is necessary to make changes to the style of research in a large number of Spanish conservatories which are too obsessed with dressing up as scientism the artistic activities they carry out, while remaining unaware that the marking out of what is (or is not) science and what is (or is not) art is not a matter of divine dogma but social constructions (GUTIÉRREZ, 2014). We started from this premise when we set out to carry out this research, and it led us to consider different methodological options and to seek out those which enabled us to contemplate the artistic process in its complexity. We wanted to explore the interpretative possibilities which the oboe concerto offered us without renouncing an analysis of its main characteristics - inevitable due to the enormous complexity and difficulty the work presents - and we also wanted these results to yield benefits for the students. And this was how we arrived at this a/r/tographic method and to our proposal to adapt Artistic Research to music.

Perhaps the most interesting element of the process that we developed, and also that which proved most complicated to draw together in a report, was the full realization of the crumbling of the frontiers so strongly established between the subject who researches and the object researched. Our research process escaped this linearity, which- in our opinion, is simply not present in the professional practice of a conservatory teacher who undertakes simultaneously an investigative, artistic and teaching role. This last-mentioned role, when combining the other two, produced several benefits that we had not fully foreseen. It did not only serve to introduce the students to the research process (one of our objectives), but also encouraged them to not be afraid to explore different interpretative possibilities and to develop their own artistic judgment, which was based more on their own reflections than on the decision of a teacher.

There is no doubt that methodological changes are slow and involve substantial changes in the mentality of communities of practice yet it is a priority that in the research carried out by musicians who are also teachers we should properly value the complexity of their own professional work and that we acknowledge that a musician's teaching involves research (GUTIÉRREZ, 2014). We believe that the a/r/tographic method has much to say in this respect.

\section{Notes}

1 ...'some meaning to a field that reqtuires clarity'

2 'must be carried out with the discernment and rigor worthy of scientific research'

3 ...'as someone would follow a set of assembly instructions'

4 ...'from their own creative and interpretative practice'.

5 ...'rather than have three separate perspectives, each confined to their respective professional activities, why not bring them together in one strong, conceptual unity?'

6 These words were written by de Lancie on the back of the photograph he had taken with the composer

7 This device sought to revolutionize musical interpretative practice in wind instruments. It involved a system of air production invented and patented in 1912 by the musician Bernhard Samuels. It consisted of an air hose located beside the foot of the musician which reached up to the mouthpiece of the instrument, in this case as far as the reed of the oboe. When the musician pressed the pedal with their foot, it generated a current of air which seemed to help them sustain o which seemed to help them avoid overstraining on the long phrases.

8 See bibliography.

9 This whole process was recorded on video, right from the start of our research, and it included class auditions with and without an audience - and an end-of-course concert, debates and seminars. 


\section{References}

BLOOM, Peter. History, memory, and the oboe concerto by Richard Strauss. Quarterly Journal of the International double reed society, International double reed society, v. 28 (3), p.77-95. 2005.

BORGDORFF, Henk. El debate sobre la investigación en las artes. Cairon: revista de ciencias de la danza, Universidad de Alcalá de Henares, v. 13, p. 25-46, 2010.

BROSCHE, Gunter. The Concerto for Oboe and Small Orchestra (1945): Remarks about the Origin of the Work based on a Newly Discovered Source. In GILLIAM, Bryan (Ed.). Richard Strauss: New Perspective on the Composer and His Work. London: Duke University Press, 2012, p.177-192.

BROWN, Andrew R.; SORENSEN, Andrew. Integrating Creative Practice and Research in the Digital Media Arts. In: SMITH, Hazel; DEAN, Roger T. (Ed.). Practice-led Research, Research-led Practice in the Creative Arts. Edinburgh: Edinburgh University Press, 2008. p.153-165.

CROFT, John. Composition is not research. Tempo, Cambridge University Press, v. 69, n. 272, p. 6-11, 2015.

GOUZOUASIS, Peter. A Reunification of Musician, Researcher, and Teacher: A/r/tography in Music Research. Arts and Learning Research Journal, Burlington, v. 22, n. 1, 23-42, 2006.

GUTIÉRREZ, José. La interpretación de las Metodologías de Investigación Basadas en las Artes, a la luz de las metodologías cualitativas y cuantitativas en la Investigación Educativa. In: MARÍN, Ricardo; ROLDÁN, Joaquín; MOLINET, Xabier (Eds.). Fundamentación, criterios y contextos en Investigación basada en Artes e Investigación Artística. Granada: Universidad de Granada, 2014. p. 25-42.

HABERMAS, Jürgen. Ciencia y técnica como ideología. $1^{\mathrm{a}}$ ed. en español, 1968. Madrid: Tecnos, 1986. 58p.

HERNÁNDEZ, Fernando. La investigación basada en las artes. Propuestas para repensar la investigación en educación. Educatio Siglo XXI, Universidad de Murcia, v. 26, p. 85-118, 2008. Available on http://revistas.um.es/educatio/article/view/46641. Accessed: 2016-02-20

IRWIN, Rita L.; BICKEL, Barbara; TRIGGS, Valerie; SPRINGGAY, Stephanie; BEER, Ruth; GRAUER, Kit; SAMESHIMA, Pauline. The rhizomatic relations of A/r/tography. Studies in Art Education. Journal of Issues and Research, British Columbia (Canada), v. 48, n.1, p. 70-88, 2006.

LÓPEZ-CANO, Rubén. La investigación artística en los conservatorios del espacio educativo europeo. Discusiones, modelos y propuestas. Cuadernos de Música Iberoamericana, Universidad Complutense, v. 25-26, p. 223-241, 2013.

LÓPEZ-CANO, Rubén; SAN CRISTOBAL, Úrsula. Investigación artística en música: problemas, métodos, paradigmas, experiencias. Barcelona: ESMUC, 2014. 258p.

LYOTARD, Jean-François. La condición postmoderna: Informe sobre el saber. $1^{\mathrm{a}}$ ed. en francés, 1979. Madrid: Cátedra, 1987. 68p.

MARÍN, Ricardo. La Investigación en Educación Artística. Educatio Siglo XXI, Universidad de Murcia, v. 29, n. 1, p. 211-230, 2011. Available on <http://revistas.um.es/educatio/article/ view/119951. Accessed: 2016-03-25.

MOLTÓ, Jorge L. La investigación artística en las enseñanzas superiores de música. Tenerife: Sociedad Latina de Comunicación Social, 2016. 175p. Available on <http://www. cuadernosartesanos.org/cba47.pdf>. Accessed: 2017-01-24.

MORENO, María Isabel; VALLADARES, Guadalupe; MARTÍNEZ, María. La investigación para el conocimiento artístico. ¿Una cuestión gnoseológica o metodológica? In: MORENO, María 
Isabel; LÓPEZ-PELÁEZ, María Paz. Reflexiones sobre investigación artística e investigación educativa basada en las artes. Madrid: Síntesis, 2017, p. 27-42.

PACE, Ian. Composition and performance can be, and often have been, research. Tempo, Cambridge University Press, v. 70, n. 275, p. 60-70, 2015.

PÉREZ-LÓPEZ, Héctor. Método y experimentalidad en una tesis doctoral artística. In: CONGRÉS INTERNACIONAL INVESTIGACIÓ EN MÚSICA, 1., 2010, Palau de Pineda (Valencia). Libro de actas. Valencia: Iseacv, 2010. p.13-17. Available on < http://www.iseacv.gva. es/documents/162972573/164148014/Congres_Internacional_Investigacio_Musica_ISEACV. pdf/80d8900d-a35e-424a-9883-676977a83cd9 > . Accessed: 2017-07-01.

REEVES, Camden. Composition, research and pseudo-science: a response to John Croft. Tempo, Cambridge University Press, v.70, n. 275, p. 50-59, 2015.

SLIGTER, Jurrien. Performer and Research. Dutch journal of music theory, Amsterdam University Press, v. 12, n. 1, p. 41-50, 2007.

SPRINGGAY, Stephanie; IRWIN, Rita L.; KIND, Sylvia Wilson. A/r/tography as Living Inquiry Through Art and Text. Qualitative Inquiry, Illinois, v. 11, p. 897-912, 2005.

STRAUSS, Richard. Strauss Oboe Concerto. Leon Goossens, oboe, The Philarmonia Orchestra,

Alceo Galliera, conductor. Vinyl, LP. Kingsway Hall, London, 1947. Available on $<$ https://www. youtube.com/watch?v=3beWxKdz_LA $>$. March 30, 2017.

STRAUSS, Richard. Konzert für oboe und Kleines Orchester. Lotar Koth, oboe, Berliner Philharmoniker, Herbert von Karajan, conductor. Vinyl LP. Berlin, Germany: Deutsche Grammophon, 1971.

STRAUSS, Richard. Strauss Oboe Concerto. John de Lancie, oboe, Max Wilcox, conductor. CD 7989-2-RG. Sony Music Entertainment, 1991.

STRAUSS, Richard. Oboe Concerto. Gordon Hunt oboe, Radio Synphonie Orchester Berlin, Vladimir Ashkenazy, conductor. CD 436 415-2. London. The Decca Record, 1993.

STRAUSS, Richard. Oboe Concerto. Thomas Indermuhle, oboe, Orchestre de Bretagne, Claude Schnitzler, conductor. CD 30CM-346. Rennes Opera in France, 1993.

STRAUSS, Richard. Renée Fleming: Richard Strauss - Four Last Songs for Soprano and Orchestra. Claudio Abbado, conductor, Lucerne Festival Orchestra, 2004. Available on <https://www. youtube.com/watch?v=z5xFL-iFh0Q $>$ Accessed: 2017-07-01.

STRAUSS, Richard. Oboe Concerto. Richard Strauss. José Antonio Masmano, oboe, Orquesta Ciudad de Granada, Josep Pons, Director, 2006. Available on <https://www.youtube.com/ watch?v=GFpKWEluRmg $>$ Accessed: 2017-02-02.

STRAUSS, Richard. (06/08/2007) Strauss Oboe Concerto Proms 'Live' 2007. Alexei Ogrintchouk, oboe, Radio Philarmonic Orchestra, Gennadi Rozhdestvensky, conductor, 2007. Available on <https://www.youtube.com/watch?v=MLUrD8veYHU> Accessed: 2017-03-12

STRAUSS, Richard. (2010) Richard Strauss - Oboe Concerto, TrV 292 (1945). François Leleux, oboe, Swedish Radio Symphony Orchestra, Daniel Harding, conductor, 2007. Available on <https://www.youtube.com/watch?v=gUCtstlCDj8> Accessed: 2017-03-22

STRAUSS, Richard. Strauss - Oboe Concerto in D major. Manfred Clement, oboe, Staatskapelle Dresden, Rudolf Kempe, conductor), 2013. Available on <https://www.youtube.com/ watch?v=YS3mD2Mb_bo $>$ Accessed: 2017-04-23

STRAUSS, Richard. Richard Strauss - Concerto for Oboe in D Major. Marin Tinev Oboe, Orchestra of the Trossingen Musikhochschule, Sebastian Tewinkel, Conductor, 2013 Available on <https://www.youtube.com/watch?v=AprDqEvUtmI > Accessed: 2017-05-02 
STRAUSS, Richard. Oboe Concerto - (Thomas Indermühle, Oboe, Orquesta Filarmónica de la UNAM, 2014. Available on <https://www.youtube.com/watch?v=RjxSQRMx4uk> June, 14, 2018

STRAUSS, Richard. Richard Strauss: Konzert für Oboe und Orchester in D-Dur. Ramon Ortega Quero, oboe, Sinfonieorchester Liechtenstein, Florian Krumpöck, Conductor, 2014. Available on <https://www.youtube.com/watch?v=WdMi6K0cc2Q> Accessed: 2017-05-02

STRAUSS, Richard. Viola Wilmsen, Strauss: Oboe Concerto. Viola Wilmsen, oboe, Kammerphilharmonie Graubünden, Achim Fiedler, Conductor, 2014. Available on <https:// www.youtube.com/watch?v=MihgjguZK-4 > September 14, 2018

STRAUSS, Richard. Richard Strauss Oboe Concerto D Major. Heinz Holliger, oboe, New Philharmoniker Orchestra, Edo de Waart, Conductor, 2014. Available on <https://www.youtube. $\mathrm{com} /$ watch?v=Cn_WtQ-sH-8> October 21, 2018

STRAUSS, Richard. Los conciertos de La 2 - Concierto RTVE A-17. Lucas Macías, oboe, Orquesta de Radio Televisión Española, Leopold Hage, conductor, 2014. Available on <http://www.rtve.es/ alacarta/videos/los-conciertos-de-la-2/conciertos-2-concierto-rtve-17/2531650/> September 23, 2018.

STRAUSS, Richard. Richard Strauss: Concerto for Oboe in D Major/Washington Barella. Washington Barella, oboe, Symphonieorchester der UDK Berlin, Eckart Hübner, Conductor, 2014. Available on <https://www.youtube.com/watch?v=L5FVQWFM60c > March, 12, 2019

STRAUSS, Richard. Ivan Podyomov plays Richard Strauss oboe concerto. Ivan Podyomov, oboe, Kansai Philharmonic Orchestra, Taijiro Iimori, Conductor, 2014. Available on $<$ https://www. youtube.com/watch?v=Mf33CZiSVQQ $>$ June, 2, 2019

STRAUSS, Richard. Richard Strauss: Oboe Concerto - Alex Klein Daniel Barenboim Chicago Symphony Orchestra. Alex Klein, oboe, Chicago Symphony Orchestra, Daniel Barenboim, conductor, 2015. Available on <https://www.youtube.com/watch?v=ltMo1st_Jss > April 23, 2019

STRAUSS, Richard. [Stefan Schilli \& VNSO] Richard Strauss - Oboe Concerto in D Major. Stefan Schilli, oboe, 2015. Available on <https://www.youtube.com/watch?v=e8c16sm8k8w >

STRAUSS, Richard. (21/02/2016) Cristina Gómez Godoy: R. Strauss Oboe Concerto @ Color Philharmonic Orchestra 5th concert. Cristina Gómez Godoy, oboe, Color Philharmonic Orchestra, Matthias Glander, Conductor. Available on <https://www.youtube.com/ watch?v=YyFY06oN1jM > January, 23, 2019

STRAUSS, Richard. Recitales Congreso AFOES Murcia 2016. Miriam Pastor Burgos, oboe, Orquesta Sinfónica de la Región de Murcia, Paul Dombrecht, conductor, 2016. Available on <http://webtv.7tvregiondemurcia.es/retransmisiones/clasica-en- la-7/2016/20112016-recitalescongreso-afoes-murcia-2016/> June, 22, 2019

ZALDÍVAR, Álvaro. Las Enseñanzas Musicales y el nuevo Espacio Europeo de Educación Superior: el reto de un marco organizativo adecuado y la necesidad de la investigación creativa y "performativa". Revista Interuniversitaria de Formación del Profesorado, Universidad de Zaragoza, v. 19, n.1, p. 95-122, 2005.

ZALDÍVAR, Álvaro. Investigar desde el arte. Anales, Real Academia Canaria de Bellas Artes de San Miguel Arcángel, v. 1, n 1, p. 57-64, 2008.

ZALDÍVAR, Álvaro. Investigar desde la práctica artística. In: CONGRÉS INTERNACIONAL INVESTIGACIÓ EN MÚSICA, 1, 2010, Palau de Pineda (Valencia). Libro de actas. Valencia: Iseacv, 2010. p. 124-129. Available on <http://www.iseacv.gva.es/documents/162972573/164148014/ Congres_Internacional_Investigacio_Musica_ISEACV.pdf/80d8900d-a35e-424a-9883676977a83cd9>. Accessed: 2017-05-02. 
María Paz López-Pelaez Casellas: Profesora Contratada Doctora - área Didáctica de la Expresión Musical. Directora de Secretariado de Proyección de la Cultura, Universidad de Jaén, España.

Cecilio García-Herrera: Catedrático de oboe en el Conservatorio Superior de Música “Andrés de Vandelvira” de Jaén y Doctor por la Universidad de Jaén. Desde el año 1998 ha sido profesor de oboe de la Junta de Andalucía. Actualmente compagina su labor docente con la interpretativa como integrante en diferentes formaciones y orquestas como: Philharmonic Partiture, Proyecto Arsian Música y Ensemble de Cámara de Jaén "ENCAJA". Es director de BAEZAFST "Festival Internacional de Música y Artes Escénicas de Baeza”. 